\title{
ANALYSIS OF CLASSROOM INTERACTION USING FLANDER INTERACTION ANALYSIS CATEGORIES SYSTEM (FIACS) IN ENGLISH CLASS-UNKRISWINA SUMBA
}

\author{
Suryani Kurniawi Kahi Leba Kapoe \\ Universitas Kristen Wira Wacana Sumba \\ suryani@unkriswina.ac.id
}

\begin{abstract}
Classroom interaction relates to teachers' teaching style in determining the interaction occurs in the classroom. Teachers' teaching style like teacher-centered will make students more passive in the classroom since the teacher talks all the time. The purpose of this research aimed to find out the percentage of the teachers' and students' talking time during classroom interaction and teacher-students characteristics during classroom interaction in English class at Unkriswina Sumba using FIACS.This research was a qualitative research design. The subject of this research was English teacher in English class who had been teaching more than five years and four years. The result found that teacher talk ratio (TT) was high that is $82,51 \%$. Then, indirect teacher talk ratio (ITT) was 51,57.Moreover, direct teacher talk ratio (DTT) was 30,94\% while students talk ratio/percentage of students talk (PT) was $13,00 \%$. Then, silence or confusion rate (SC) was $4,48 \%$. Last, indirect and direct ratio (ID) was $166,67 \%$. The result showed that indirect talk was dominant than direct talk in the conversation class while the most dominant characteristic in conversation class was content cross that is 85.It reflected that most of the teaching-learning time was devoted to questions, lectures and praises. The result of this research enriched the knowledge of the students, lectures, and other language learners that in the classroom, both the lectures and students should have the willingness to participate in the interaction.
\end{abstract}

Keyword: Classroom Interaction, FIACS System, Teacher's talk, Student's talk,

\section{INTRODUCTION}

Interaction is the essence of communication. Learning to interact in English means learning to communicate in English. Teaching and learning process is an example of interaction, it involves interaction between teacher and students in which they influence each other in the classroom. The elements (learners and teacher) are not able to stand by themselves or they always need some help to interact each other because the learning process is named success when there is a positive feedback from the students. Teaching process actually gives a chance for learners to ask, to guess, to think and even to the course material in order to make interaction between students. Interaction in the classroom has played a significant role. Everybody may learn something better if he/she experiences it by himself. When the students are engaged indirect classroom activities, they will learn better. It is also stated that learning successes are determined by the quality of interaction between teacher and students during the learning activity. The students who are active in conversation through talking turns may develop their language. Meanwhile, those who are passive in conversation will have less opportunity to learn. Classroom interaction as a two-way process between the participants in the learning process. The teacher influences the learners and vice versa (Dagarin, 2004). Classroom interaction became an important feature of teaching learning process. Through classroom interaction, the teacher can encourage the students to speak because in stimulating the students to think, understand, and give respond. In fact, creating communicative interaction between teacher and the students is one of the problems in teaching and learning process.

Moreover, when the researcher observed some teaching and learning process of English class, the researcher found that the common interaction that occurred in the classroom was the students would participate to talk if the teacher initiated, encouraged, and asked them to talk. In 
fact, the type of teacher talk had great influence to make the students to talk in the classroom. It was the basic reason why the researcher wanted to know how much the teacher and students took time to talk during teaching and learning process.

Flanders' Interaction Analysis Categories System (FIACS) is appropriate for analyzing the students' and teacher's talk at EFL context since the technique is to measure how much the teacher and students take talking during teaching and learning process. The teaching learning situations in the classroom involve interaction between the teacher and the students. The Flanders' Interaction Analysis Category System (FIACS) records what the teacher and the students do or say during teaching and learning process (Flander, 1970) as cited in (Asmara, 2007).

In addition, some studies have been conducted by the researchers in investigating classroom interaction. (Ulan, 2017) who investigated classroom interaction states that the teacher talk dominated the classroom interaction. She always made the classroom interaction in teachinglearning of speaking more active by her questions, explanations and direction. The teacher stimulates her students by asking questions and giving directions, she even praises or encourages. The praises or encourages would gave the students a high motivation to learn English. Then, the research from (Nurmasitah, 2010) found that 1) the most dominant characteristic in immersion classroom interaction was the content cross (that most of the teaching-learning time was devoted to questions and lectures by the teacher), 2) the teacher spent $57.43 \%$ of the teaching-learning time, while the students spent $22.20 \%$ of the teachinglearning time that showed that the students were active enough in the classroom interaction, and 3 ) the teaching effectiveness elements used in the classroom were in the form of academic learning time, use of reinforcement, cues and feedback, co-operative learning, classroom atmosphere, higher order questions, advance organizers, direct instruction, indirect teaching, and the democratic classroom.

Based on the previous research above, classroom interaction that was intended in this research was how the teacher and students participate to talk during teaching and learning process. In fact, according to (Tuan \& Nhu, 2010), teacher talk is dominant in classroom interaction. Therefore, the researcher would like to analyze classroom interaction. Through the classroom interaction, the researcher would know the teachers' and students' talking time and characteristic.

\section{METHOD}

This research was a qualitative research design. Qualitative design will be chosen in order to explore and understand the social phenomenon(Creswell, 2014). In order to describe the interaction between teacher and student in the classroom, the writer used descriptive study. The strategy applied will be an observation since classroom interaction is suitable as observation that is for categorizing into which all relevant talk. Then, through Flander's Interaction Analysis Categories (FIACS), the researcher described the result of this research by showing the percentage of teacher's and student's talk; and teacher's and student's characteristics. In addition, researcher used observation sheet, recording, transcribing, coding and analyzing to collect the data. In this study, the phenomena explored and understood was about classroom interaction in English class. 
The population of this research was all English lectures who taught English Course and there were five English lectures in Unkriswina Sumba. The sample of this research was two lectures who teach English class. They had been observed seven times in different classes. Thus, the total observation was 14 times. different classes. Thus, the total observation was 14 times.

In conducting this research, the researcher used two instrument that included observation tally sheet and recording (audio recording). Through the observation tally sheet, the researcher got expected data since the researcher would put out code on the particular teacher or students talk during the teaching and learning process. Before the researcher filled the observation tally sheet, the researcher had to understand observation tally sheet's guidance that included list of Flander's Interaction Analysis Categories (FIAC) that the researcher adapted from Flander (1970) cited in(Hai SK, 2006). These rules are as recommended by Flander (1970) cited in(Hai SK, 2006) had to be followed by the researcher as follow:

Table 1. Some rules for deciding which category should be put code consistently

\begin{tabular}{|c|c|}
\hline Rule 1 & $\begin{array}{l}\text { When it is not certain in which of two or more categories a statement belongs, } \\
\text { choose the category that is numerically farthest from the category } 5 \text {. For e.g, if an } \\
\text { observer is not sure whether it is } 2 \text { or } 3 \text { then choose } 2 \text {. If in doubt between } 5 \text { and } 7 \text {, } \\
\text { he chooses } 5 \text {. }\end{array}$ \\
\hline Rule 2 & $\begin{array}{l}\text { The observer should not involve his personal viewpoint. If a teacher attempts to be } \\
\text { clever, students see his statements as critic of students; the observer sues category } \\
7 \text {. }\end{array}$ \\
\hline Rule 3 & $\begin{array}{l}\text { If more than one category is active in a spain of } 3 \text { seconds, and then all the } \\
\text { categories should be recorded. If after } 3 \text { seconds, no category changes, then the } \\
\text { same serial number should be repeated in the next } 3 \text { seconds. }\end{array}$ \\
\hline Rule 4 & $\begin{array}{l}\text { If the time period of silence exceed } 3 \text { seconds, it should be recorded under the } \\
\text { category No } 10\end{array}$ \\
\hline Rule 5 & $\begin{array}{l}\text { When teacher calls a child by name, the observer is supposed to record a 4th } \\
\text { category }\end{array}$ \\
\hline Rule 6 & $\begin{array}{l}\text { When the teacher repeats the student's answer and the answer is a correct, that is } \\
\text { recorded as a category No } 2 \text { this tells the student that he has the right answer and } \\
\text { therefore functions as praise or encouragement. }\end{array}$ \\
\hline Rule 7 & $\begin{array}{l}\text { When a teacher listens to a student and accepts his ideas for a discussion, then this } \\
\text { behavior belongs to category No } 3 \text {. }\end{array}$ \\
\hline Rule 8 & $\begin{array}{l}\text { The words "All is ok", "yes", "yah", "hum", "alright", etc belong to the category } \\
\text { No } 2 \text { (encouragement) }\end{array}$ \\
\hline Rule 9 & $\begin{array}{l}\text { If a teacher jokes without aiming at any students, this behavior belongs to the } \\
\text { category No } 2 \text {. But if he makes any joke aiming at some particular students, then it } \\
\text { belongs to the category No } 7 \text {. }\end{array}$ \\
\hline Rule 10 & $\begin{array}{l}\text { When all the students respond to a very small question collectively, then the serial } \\
\text { number of category } 8 \text { is recorded. }\end{array}$ \\
\hline
\end{tabular}

Moreover, after recording, the researcher made the transcription. Everything that the students had said and done in the conversation should be transcribed. It was aimed to get more valid data about the activity done by the participants. It was also needed to help the researcher in analyzing the data coming from the activity then coding. After collecting the data, the researcher analyzed the 
data from the observation sheet of Flander Interaction Analysis and video record. Then, the researcher calculated how much the teacher and students talk in classroom interaction by using Flander's formulates in order to get expecting data.

\section{FINDINGS AND DISCUSSION}

As mentioned in the research methodology, to get the data, the researcher conducted observation using observation tally sheet and recording. In addition, to know the percentage of talk time during the classroom interaction, the researcher used Flander's formulate. Then, to know the characteristics of the students and the lecture, the researcher used Flander's Interaction Matrix. Finally, after all of the data collected, the researcher analyzed each data firstly. The result of classroom observation and recording described the reality of classroom interaction between the lecture and the students. Below the percentage of talk time during the classroom interaction:

Table 2 The percentage of talk time

\begin{tabular}{clc}
\hline Number & \multicolumn{2}{c}{ Classrom Interaction } \\
\hline 1 & Teacher Talk Ratio & $82,51 \%$ \\
2 & Indirect Teacher Talk Ratio & $51,57 \%$ \\
3 & Direct Teacher Talk Ratio & $30,94 \%$ \\
4 & Student's Talk Ratio & $13,00 \%$ \\
5 & Silence or Confusion Ratio & $4,48 \%$ \\
6 & Indirect and Direct Ratio & $166,67 \%$ \\
\hline
\end{tabular}

\section{Teacher Talk Ratio/TT}

Based on the data of the talk time during the conversation class, it was found that the teacher talk ratio is $82,51 \%$. In fact, the role of lecture in the classroom interaction had a great impact to the result of the findings. In this case, when students have low motivation to build a communication in the classroom during the class, then the lecture/teacher tend to hold the class in order to decrease the rigid situation in the classroom. The case showed the lecture has the main role in controlling the class. In addition, the lecture was in a big effort create the atmosphere in the classroom to stimulate student's motivation to interact to other students and to the lecture/teacher. Moreover, the lecture spent much talk time during the classroom interaction.

\section{Indirect Teacher Talk Ratio/ITT}

The talk time during the conversation class found that the indirect teacher talk ratio is $51,57 \%$. The result showed that the lecture indirectly showed her response to the students' feelings and accepting students' feelings, accepting students' ideas by clarifying and developing their ideas mostly. In addition, the lecture indirectly praises her students and encouraging them to interact with other students in the classroom. Moreover, in order to know students' knowledge or concept about the lesson, so the lecture indirectly asked questions mostly during the classroom interaction. The lecture supported students' participation during the classroom interaction. 


\section{Direct Teacher Talk Ratio/DTT}

Based on the data of the talk time during the conversation class, it was found that the direct teacher talk ratio is $30,94 \%$. The result showed that the lecture diminished her lecturing, giving direction and criticizing the students. Seemingly, the lecture gave chance to the students to comprehend the content or concept of the lesson themselves without giving lecturing or giving direction and commands. In this case, the lecture builds students' motivation to learn independently.

\section{Students' Talk Ratio/Percentage of Students Talk/ST}

It was found that the student's talk ratio is $13,00 \%$. The result showed that students' participation in the conversation class was low. In this class, there were two or three students who speak actively and response to the lecture's question. Most of them, doing usual activity and await directions, commands or lecturing from the lecture. Therefore, it seemed the lecture had a main control in the class because most of the students had low motivation to speak and interact with other students. The lecture tried to encourage and motivate them by giving praise or jokes to stimulate their willingness to speak bravely.

\section{Silence or Confusion Ratio/SC}

Based on the data of the talk time during the conversation class, it was found that the silence or confusion rate is $4,48 \%$. The result showed that silence or confusion in the conversation class was very low. It means that there was a little confusion in communication during the class in a short period. Moreover, the activity in the conversation class was recorded well so that it diminished the confusion of communication.

\section{Indirect and Direct Ratio I/D}

Based on the data of the talk time during the conversation class, it was found that the indirect and direct ratio is $166,67 \%$. The result showed that indirect talk was dominant than direct talk in the conversation class. The lecture giving questions, praising and encouraging students, giving jokes, and developing student's ideas or concepts mostly during the conversation class. In fact, the students have low motivation to create communication in the class. Then, the lecture indirectly pushed the students to speak up.

Then, the researcher identifies students' and teachers' characteristics during classroom interaction by referring to the Flander's Interaction Matrix. The finding result is below: 
Table 3 Matrix of classroom interaction in English class-Unkriswina Sumba

\begin{tabular}{|c|c|c|c|c|c|c|c|c|c|c|c|c|c|}
\hline & & & \multicolumn{3}{|c|}{ Teacher Indirect Talk } & \multicolumn{4}{|c|}{ Teacher direct talk } & \multicolumn{2}{|c|}{ student talk } & \multirow[b]{2}{*}{$\begin{array}{c}\text { silence } \\
\text { or pause }\end{array}$} & \multirow[b]{2}{*}{$\begin{array}{c}\text { tota } \\
1\end{array}$} \\
\hline & & & $\begin{array}{c}\text { Accept } \\
s\end{array}$ & $\begin{array}{c}\text { Praise Or } \\
\text { Encourageme }\end{array}$ & $\begin{array}{l}\text { Accpet } \\
\text { s Or }\end{array}$ & $\begin{array}{l}\text { Asking } \\
\text { Questio }\end{array}$ & $\begin{array}{c}\text { Lecturing/Lectu } \\
\text { re }\end{array}$ & $\begin{array}{l}\text { Giving } \\
\text { directio }\end{array}$ & $\begin{array}{c}\text { Criticizin } \\
\text { g or }\end{array}$ & $\begin{array}{l}\text { student } \\
\text { talk }\end{array}$ & $\begin{array}{l}\text { student } \\
\text { talk }\end{array}$ & & \\
\hline & & & 1 & 2 & 3 & 4 & 5 & 6 & 7 & 8 & 9 & 10 & \\
\hline \multirow{3}{*}{$\begin{array}{c}\text { Teach } \\
\text { er } \\
\text { Indirec } \\
\text { t Talk }\end{array}$} & Accepts Feeling & 1 & 4 & 3 & 6 & 3 & 1 & 3 & 3 & 4 & 0 & 4 & 31 \\
\hline & $\begin{array}{c}\text { Praise Or } \\
\text { Encouragemen }\end{array}$ & 2 & 0 & 7 & 2 & 2 & 0 & 3 & 1 & 1 & 3 & 3 & 22 \\
\hline & $\begin{array}{l}\text { Accpets Or } \\
\text { uses ideas of }\end{array}$ & 3 & 4 & 0 & 6 & 3 & 1 & 0 & 3 & 4 & 0 & 5 & 26 \\
\hline \multirow{4}{*}{$\begin{array}{l}\text { Teach } \\
\text { er } \\
\text { direct } \\
\text { talk }\end{array}$} & $\begin{array}{c}\text { Asking } \\
\text { Question }\end{array}$ & 4 & 5 & 2 & 2 & 6 & 4 & 3 & 6 & 2 & 2 & 4 & 36 \\
\hline & $\begin{array}{c}\text { Lecturing/Lectu } \\
\text { re }\end{array}$ & 5 & 1 & 1 & 3 & 3 & 7 & 3 & 3 & 1 & 5 & 2 & 29 \\
\hline & $\begin{array}{c}\text { Giving } \\
\text { directions }\end{array}$ & 6 & 2 & 2 & 1 & 3 & 0 & 7 & 0 & 5 & 2 & 1 & 23 \\
\hline & $\begin{array}{l}\text { Criticizing or } \\
\text { iustifying }\end{array}$ & 7 & 0 & 1 & 2 & 2 & 1 & 1 & 5 & 0 & 0 & 5 & 17 \\
\hline \multirow{4}{*}{$\begin{array}{l}\text { studen } \\
\text { t talk }\end{array}$} & $\begin{array}{l}\text { student talk } \\
\text { response }\end{array}$ & 8 & 0 & 2 & 1 & 1 & 0 & 3 & 1 & 6 & 1 & 3 & 18 \\
\hline & $\begin{array}{l}\text { student talk } \\
\text { initiation }\end{array}$ & 9 & 1 & 1 & 2 & 0 & 0 & 1 & 0 & 1 & 3 & 2 & 11 \\
\hline & $\begin{array}{c}\text { silence or } \\
\text { pause or }\end{array}$ & $\begin{array}{l}1 \\
0 \\
\end{array}$ & 1 & 0 & 0 & 1 & 2 & 0 & 0 & 1 & 0 & 5 & 10 \\
\hline & total & & 18 & 19 & 25 & 24 & 16 & 24 & 22 & 25 & 16 & 34 & 223 \\
\hline Data & \begin{tabular}{|l} 
Teacher S \\
Content \\
Teacher
\end{tabular} & $\frac{000}{0.55}$ & & & \begin{tabular}{|l|}
32 \\
85 \\
13
\end{tabular} & \multicolumn{2}{|c|}{$\begin{array}{l}\text { Highest Value: } \\
\text { Most Dominant : }\end{array}$} & int Cross & & & & & \\
\hline
\end{tabular}

From the data above, the researcher found that the most dominant characteristic in conversation class was content cross that is 85 . The data showed the general characteristics that usually happened in classroom interaction were content cross. Moreover, the result showed that asking question, lecturing, giving direction, criticizing or justifying were the most activities appeared in the conversation class.

\section{CONCLUSIONS}

Based on the data analysis and the result of the study, it can be concluded that teacher talk ratio (TT) was high and showed most of the classroom interaction in conversation class was handled and controlled by the lecture. Indirect teacher talk ratio (ITT) showed that lecture indirectly showed her response to the students' feelings and accepting students' feelings, accepting students' ideas by clarifying and developing their ideas mostly.Direct teacher talk ratio (DTT) reflected the lecture diminished her lecturing, giving direction and criticizing to the students. In this case, the lecture builds students' motivation to learn independently.Students talk ratio/percentage of students talk (ST) showed that students' participation in the conversation class was low. In this class, there were two or three students who speak actively and response to the lecture's question. Silence or confusion rate (SC) showed that silence or confusion in the conversation class was very low. It means that there was a little confusion in communication during the class in a short period.Indirect and direct ratio (ID) showed that indirect talk was dominant than direct talk in the conversation class. The most dominant characteristic in conversation class was content cross and reflected that most of the teaching-learning time was devoted to questions, lectures and praises.

The results of the research indicate that the classroom interaction in each meeting has similar pattern; content cross and teacher's talking were the dominant characteristics. The classroom interaction was not active enough. The lecture still controlled all of the teaching-learning activities, and there were two or three students who active in the class. For this reason, it is better to mix the teaching-learning time by varied material. In addition, it is better if the lecture gives more reinforcements to the students. Reinforcements could increase the frequency of productive behaviors and decrease the frequency of disruptive behaviors. 


\section{REFERENCES}

Asmara, T. R. (2007). An Analysis on the Speaking Classroom Interaction at The Tenth Grade of SMA Negeri 7 Surakarta In The Academic Year 2006 / 2007 Submitted to the Teacher Training and Education Faculty of Sebelas Maret University as a Fulfillment of the Requirements for G. English Department, Teacher Training and Education Faculty, Sebelas Maret University.

Creswell, J. (2014). Research Design-Qualitative-Quantitative-Mixed methods-Approach. SAGE Publications.

Dagarin, M. (2004). Classroom Interaction and Communication Strategies in Learning English as a Foreign Language. ELOPE: English Language Overseas Perspectives and Enquiries, 1(1-2), 127-139. https://doi.org/10.4312/elope.1.1-2.127-139

Hai SK, B. L. (2006). Effectiveness Of Interaction Analysis Feedback On The Verbal Behaviour Of Primary School Mathematics Teachers. Malaysian Journal of Educators and Education, 21, 115-128. http://myais.fsktm.um.edu.my/6560/

Nurmasitah, S. (2010). A Study of Classroom interaction characteristic in a geography class Sita Nurmasitah (ryan 20411038).pdf. 1-130.

Tuan, L. T., \& Nhu, N. T. K. (2010). Theoretical Review on Oral Interaction in EFL Classrooms. Studies in Literature and Language, 1(4), 29-48.

Ulan, D. A. (2017). An Analysis of Classroom Interaction in the Teaching-Learning Process of Speaking at Tenth Grade Students of Smk Al-Husain Keling in the Academic Year of 2017/2018. Jurnal Edulingua, Vol 4(2), pp.8. 